\title{
Strategi Promosi Perpustakaan Dalam Meningkatkan Minat Baca Masyarakat Di Dinas Perpustakaan Dan Arsip Provinsi Nusa Tengara Barat 2020
}

\author{
Lubis $^{1}$, Iwin Ardyawin ${ }^{2}$, Widiyastuti Furbani ${ }^{3}$ \\ IProdi DIII Perpustakaan, Universitas Muhammadiyah Mataram \\ 2Prodi DIII Perpustakaan, Universitas Muhammadiyah Mataram \\ 3Prodi DIII Perpustakaan, Universitas Muhammadiyah Mataram
}

$\underline{\text { lubis.vharoso@gmail.com }}$

\section{INFO ARTIKEL}

\section{Riwayat Artikel:}

Diterima: 29-02-2020

Disetujui: 14-03-2020

\section{Kata Kunci:}

1. Promosi

2. Perpustakaan

3. Minat Baca

\section{ABSTRAK}

\begin{abstract}
Perpustakaan merupakan institusi yang menyediakan jasa layanan informasi, sehingga kegiatan pelayanan merupakan ujung tombak kegiatan perpustakaan. Kualitas layanan perpustakaan sangat dipengaruhi oleh kualitas pustakawan sebagai pelaksana. Kualitas pustakawan ditentukan oleh latar belakang pendidikan (keahlian), kepribadian dan kemampuan berkomunikasi. Keterampilan komunikasi sangat penting bagi pustakawan, karena dalam kegiatan layanan informasi pustakawan berhadapan langsung dengan para pengguna perpustakaan atau pencari informasi, peran seorang pustakawan di dalam sebuah perpustakaan sangat penting. Menurut Hermawan, (2006 : 56-57), Pustakawan mempunyai banyak peran antara lain, Edukator (Pendidik), Manager (Pengatur), Administrator (Pencatatan), Supervisor/penyelia (Mengawasi atau mengarahkan). Sedangkan Komunikasi mempunyai fungsi yang penting dalam manajemen. Antara lain, Fungsi informatif, Fungsi persuasi, Fungsi regulatif, Fungsi control. Peran Pustakawan sebagai educator pustakawan dalam melakukan kegiatannya secara sukarela mendidik, mengajar, dan melatih setiap pemustaka yang ingin memanfaatkan layanan informasi yang ada di UPT Perpustakaan Universitas Matara, Peran Pustakawan sebagai manager, pustakawan paling tidak telah memiliki jiwa kepemimpinan terutama memimpin diri mereka agar bekerja sesuai aturan (disiplin), Peran Pustakawan sebagai administrator, bahwa seorang pustakawan harus dapat menjadi pengelolah informasi yang baik serta bisa memanfaatan teknologi, Peran Pustakawan Supervisor/penyelia, dalam melakukan pengawasan dan pengarahan telah berperan dengan melakukan koordinasi, Peran fungsi komunikasi pustakawan telah mampu berperan dengan cara memberikan informasi.
\end{abstract}

\section{A. LATAR BELAKANG}

Promosi merupakan elemen penting dari bauran pemasaran, dikarenakan dalam bauran pemasaran terdapat seperangkat alat pemasaran yang dikenal dengan marketing mix $4 \mathrm{P}$, yaitu product (produk), price (harga), place (tempat atau saluradistribusi), dan promotion (promosi).

Permasalahan yang yang sedang dihadapi oleh Dinas Perpustakaan dan Arsip Provinsi NTB saat ini, bahwa jumlah pengunjung perpustakaan masih sangat rendah dengan rata-rata pertahun hanya 990.00o orang saja, angka ini tentu sangat kecil kalo dibandingkan dengan jumlah penduduk di NTB yang mencapai 4.835 577.00 jiwa Data BPS NTB. Permasalahan tersebut muncul disebabkan karena peran fungsi perpustakaan dalam upaya peningkatan minat baca masyarakat masih belum efektif ditambah lagi dengan kegiatan promosi yang masih sangat tradisonal, padahal promosi dalam organisasi seperti perpustakaan promosi menjadi sesuatu yang harus dilaksanakan dan juga disesuaikan dengan kepentingan dan kebutuhan perpustakaan saat ini. Sejalan dengan semangat Undang-Undang Nomor 43 Tahun 2007 Tentang Perpustakaan pasal 7 ayat 1(e) yang berbunyi bahwa, perpustakaan berkewajiban menggalakkan promosi gemar membaca dan memanfaatkan perpustakaan.

Salah satu kegiatan yang harus digalakan kepada masyarakat yaitu membaca. Menurut Ibrahim, (1996)Membaca merupakan kegiatan kompleks dan sengaja, yang melibatkan berbagai faktor yang datangnya dari dalam diri pembaca dan dari luar. Membaca dalam hal ini berupa proses berpikir yang didalamnya terdiri dari berbagai aksi fikir yang bekerja secara terpadu mengarah pada satu tujuan yaitu memahami makna paparan yang tertulis secara keseluruhan

Membaca merupakan aktivitas penting bagi terciptanya generasi-generasi yang memiliki wawasan luas dalam segala hal, dengan membaca kita dapat mengetahui, memahami dan mengerti berbagai hal untuk membuat kita peka terhadap kondisi lingkungannya. Dalam era pembangunan dewasa ini minat baca dan kebiasaan membaca sangat penting. Minat dan kebiasaan membaca membuat seseorang dapat memperoleh informasi tentang sesuatu yang dibaca, memperoleh pengertian yang lebih dalam suatu gejala, serta dapat mengaitkan dengan berbagai gejala lainnya. Secara singkat, minat dan kebiasaan membaca menghasilkan informasi, pengertian, pengetahuan, 
keterampilan, motivasi dan fakta seperti yang disajikan oleh bahan bacaan. Bangsa yang maju dapat dilihat dari tingginya minat baca masyarakat, sayangnya pada tahun 2017 Indonesia menepati urutan ke 60 dari 61 Negara dalam katagori Minat baca terendah.

Untuk mengatasi hal tersebut maka perlu ditingkatkan peran Dinas Perpustakaan dan Arsip Provinsi NTB salah satu caranya dengan melakukan promosi menggunakan pendekatan product (produk), price (harga), place (tempat atau saluradistribusi), dan promotion (promosi). Disini menjadi lebih jelas peranan dari perpustakaan yaitu sebagai tempat wahana pendidikan, penelitian, pelestarian, informasi dan rekreasi untuk meningkatkan kecerdasan bangsa dan mewujudkan tujuan Dinas Perpustakaan dan Arsip Provinsi NTB yakni meningkatkan minat baca, serta memperluas wawasan dan pengetahuan untuk mencerdaskan kehidupan bangsa.

Berdasarkan latar belakang di atas maka dalam penelitian ini peneliti mengangkat atau mengambil judul 'Strategi Promosi Perpustakaan Dalam Meningkatkan Minat Baca Masyarakat". Tujuan Penelitian

1. Tujuan Umum

Penelitian ini secara umum bertujuan untuk mengetahui Strategi Promosi Perpustakaan Dalam Meningkatkan Minat Baca Masyarakat di Dinas Perpustakaan dan Arsip Provinsi NTB.

2. Tujuan Khusus

Tujuan khusus dalam penelitian ini sebagai berikut:

3. Bagaimana strategi promosi dalam meningkatkan minat baca masyarakat di Dinas Perpustakaan dan Kerasipan Provinsi NTB?

\section{B. METODE PENELITIAN}

Metode yang digunakan dalam penelitian ini adalah metode deskriptif kualitatif, karena tujuannya adalah untuk mendeskripsikan dan menggambarkan apa adanya mengenai peran komunikasi pustakawan. Dalam hal ini guna menganalisis data yang diperoleh secara mendalam dan menyeluruh dengan harapan dapat diketahui bagaimana peran komunikasi pustakawan dalam meningkatkan pelayanan informasi di UPT Perpustakaan Universitas Mataram tahun 2017.

\section{Teknik Pengumpulan Data}

Sugiyono (2013:224) teknik pengumpulan data merupakan langkah yang paling strategis dalam penelitian, karena tujuan utama dari penelitian adalah mengumpulkan data.

Adapun teknik pengumpulan data yang digunakan oleh penelitiantara lain:

a. Observasi

Nasution (dalam Sugiyono 2013:226) menyatakan bahwa, obsevasi adalah dasar semua ilmu pengetahuan. Metode ini digunakan untuk memperoleh data secara nyata dan mengamati secara lansung peran dan fungsi komunikasi pustakawan dalam peningkatan layanan infomasi di
UPT. Perpustakaan Universitas Mataram, peneliti mengamati subyek saat berada perpustakaan, dan saat berada di luar perpustakaan dengan menggunakan pedoman observasi yang telah dipersiapkan.

b. Wawancara

Esterberg (dalam Sugiyono 2013:231) mendefinisikan wawancara adalah merupakan pertemuan dua orang untuk bertukar informasidan ide melalui tanya jawab, sehingga dapat dikonstruksikan makna dalam suatu topik tertentu. Wawancara digunakan sebagai teknik pengumpulan data apabila peneliti ingin melakukan studi pendahuluan untuk menemukan permasalahan yang harus diteliti, tetapi juga apabila peneliti ingin mengetahui hal-hal dari responden yang lebih mendalam.

c. Dokumentasi

Dokumen merupakan catatan peristiwa yang sudah berlalu. Dokumen biasa berbentuk tulisan gambar, atau karya-karya monumental dari seseorang. Hasil penelitian juga akan semakin kredibel apabila didukung oleh foto-foto atau aturaaturan yang telah ada.

d. Berdasarkan uraian di atas, dalam penelitian ini peneliti mengambil dokumentasi tentang peran dan fungsi komunikasi pustakawan dalam peningkatan layanan infomasi di UPT. Perpustakaan Universitas Mataram berupa foto-foto saat melakukan kegiatan

\section{KAJIAN PUSTAKA}

Promosi adalah mekanisme komunikatif persuasif pemasaran dengan memanfaatkan teknikteknik hubungan masyarakat. Promosi merupakan forum pertukaran antar organisasi dengan konsumen dengan tujuan utama memberi informasi tentang produk atau jasa yang ditawarkan dan yang disediakan oleh organisasi, sekaligus membujuk konsumen untuk bereaksi terhadap produk atau jasa yang ditawarkan. Promosi merupakan kegiatan penting yang dilakukan oleh setiap organisasi terutama bagi organisasi yang bergerak dalam bidang usaha dan jasa. Bagaimanapun bentuk produk dan jasa yang dihasilkan tidak ada gunanya jika tidak diketahui dan dimanfaatkan oleh sebagian konsumennya (Darmono, 2001:175).

Promosi merupakan elemen penting dari bauran pemasaran. Dalam bauran pemasaran terdapat seperangkat alat pemasaran yang dikenal dengan marketing mix 4P, yaitu product (produk), price (harga), place (tempat atau saluradistribusi), dan promotion (promosi).

Marketing mix adalah strategi mencampur kegiatan-kegiatan marketing, agar dicari kombinasi maksimal sehingga mendatangkan hasil yang paling memuaskan (Buchari Alma, 2014:130). Sedangkan menurut Kotler dan Amstrong (2012:92) Bauran pemasaran adalah perangkat pemasaran yang baik yang meliputi produk, penentuan harga, promosi, distribusi, digabungkan untuk menghasilkan respon yang diinginkan pasar sasaran.

Adapun keempat unsur marketing mix tersebut dapat diuraikan sebagai berikut: 
a. Product

Product (produk), adalah mengelola unsur produk termasuk perencanaan dan pengembangan produk atau jasa yang tepat untuk dipasarkan denga mengubah produk atau jasa yang ada dengan menambah dan mengambil tindakan yang lain yang mempengaruhi bermacam-macam produk atau jasa.

b. Price

Price (harga), adalah suatu sistem manajemen perusahaan yang akan menentukan harga dasar yang tepat bagi produk atau jasa dan harus menentukan strategi yang menyangkut potongan harga, pembayaran ongkos angkut dan berbagi variabel yang bersangkutan.

c. Place

Place (tempat atau saluran distribusi), yakni memilih dan mengelola saluran perdagangan yang dipakai untuk menyalurkan produk atau jasa dan juga untuk melayani pasar sasaran, serta mengembangkan sistem distribusi untuk pengiriman dan perniagaan produk secara fisik.

d. Promotion

Promotion (promosi), adalah suatu unsur yang digunakan untuk memberitahukan dan membujuk pasar tentang produk atau jasa yang baru pada perusahaan melalui iklan, penjualan pribadi, promosi penjualan, maupun publikasi.

Secara singkat promosi berkaitan dengan upaya untuk mengarahkan seseorang agar dapat mengenal produk perusahaan, lalu memahaminya, berubah sikap, menyukai, yakin, kemudian akhirnya membeli dan selalu ingat akan produk tersebut. Promosi terutama diarahkan pada calon pembeli yang sudah dikenal atau diketahui secara pribadi. Di dalam proses pemilihan alat-alat promosi yang digunakan, tergantung pada siapa yang akan dijangkau, apa yang akan ditawarkan, apa yang akandikomunikasikan, dan bagaimana audien menanggapai pesan. Juga tergantung pada kekuatan (strenghts) dan kelemahan (weaknesses) internal organisasi disamping peluang (opportunities) dan tantangan (threats) eksternal organisasi. Sebenarnya secara sadar ataupun tidak pustakawan sudah banyak melakukan promosi, akan tetapi kegiatan tersebut tidak/belum terencana sehingga tidak/belum mencapai tujuan maupun sasaran perpustakaan.

\section{HASIL DAN PEMBAHASAN}

\section{Strategi Promosi Pustakawan Untuk Meningkatkan Minat Baca}

Menurut Sutarno (2004: 85) "Minat adalah suatu keinginan atau kecenderungan hati yang tinggi terhadap sesuatu”. Minat baca harus dipupuk sejak dini, dalam menumbuh hal ini perpustakaan atau pustakawannya sangat berperan penting dalam menumbuh kembangkan minat pemustakaanya untuk membaca buku, maka dari itu sebuah perpustakaan harus mempunyai koleksi yang lengkap dan sesuai dengan kebutuhan para pengguna/pemustaka.

Disamping itu perpustakaan juga harus mempunyai seorang pustakawan sebagai pengelolanya yang pendidikannya minimal lulusan Diploma III perpustakaan. Di samping itu juga ada beberapa cara untuk meningkatkan minat baca pengguna/pemustaka dengan berbagai macam kegiatan yang rekreatif dan mendidik.
Dalam bauran pemasaran pustakawan terdapat alat pemasran yang dikenal dengan Marketing Mix 4p, yaitu produk, price, place, dan promotion. Marketix mix adalah strategi kegiatan yang digunakan dalam pemasran yang mendatangkan hasil yang memuaskan. Adapun keempat marketing mix dapat diuraikan sebagai berikut :

a. Produk (Produk)

Menurut Ibu Hermin salah satu pustakawan di Dinas Perpustakaan dan Kerasipan Provinsi Nusa Tenggara Barat, terebut menyatakan bagaiman koleksi perpustakaan dalam meningkatkan minat baca

"Peran koleksi adalah salah satu media yang dapat digunakan untuk menambah wawasan, pengetahuan serta mendapatkan kekayaan informasi secara gratis yang bisa di berikan oleh perpustakaan. Ada banyak koleksi yang ada di Dinas Perpustakaan Dan Kerasipan Provinsi Nusa Tenggara Barat antara lain yaitu, ada karya cetak dan non cetak yg termasuk buku, ada koleksi referensi, terbitan berkala yang termasuk koran dan majalah yang diperlukan sebagai koleksi perpustakaan karena meliputi aspek kehidupan manusia. Agar koleksi tetap bisa dimanfaatkan Dinas perpustakaan Dan Kerasipan Provinsi Nusa Tenggara Barat memilih koleksi-koleksi sesuai dengan kebutuhan pemustaka yang di layani. Selama ini yang dilakukan oleh perpustakaan daerah mataram itu adalah sebelum mengadakan koleksi terlebih dahulu melakukan survei pemakai bertujuan untuk mendapatkan informasi koleksi apa saja yang sangat di butuhkan, dari rujukanrujukan itu dari informasi yang kita dapatkan dari pemustaka, dari situlah sumber kita untuk menyeleksi koleksi yang mau kita adakan." dan di sesuaikan juga dengan kurikulum pendidikan. Kurikulum pendidikan yang digunakan sekarang itu".

Adapun yang dapat disimpulkan oleh penulis, apabila sebuah perpustakaan memiliki koleksi yang sesuai dengan kebutuhan pengguna maka pelayanan perpustakaan dapat dilakukan secara tepat guna dalam meningkatkan minat baca, oleh karena itu pustakawan harus menyeleksi koleksi dengan baik agar koleksi tersebut dapat di gunakan oleh pemustaka, dan disesuaikan dengan kebutuhan masing-masing pengguna/pemustaka.

Perpustakaan juga melakukan Up Date Informasi dengan cara pembelian/pengadaan buku baru secara sikologis koleksi baru ini akan menambah keinginan, kemauan, kepercayaan dan rasa nyaman dalam memanfaatkan informasi, sehingga di Dinas Perpustakaan dan Kerasipan Provinsi Nusa Tenggara Barat menjadikan cara tersebut sebagai salah upaya dalam meningkatkan minat baca masyarakat di Dinas Perpustakaan dan Kerasipan Provinsi Nusa Tenggara Barat.

b. Price ( Harga )

Menurut Ibu wayan Dayu salah satu pustakawan di Perpusda terebut menyatakan:

Tidak ada biaya apapun yang di tanggungkan oleh pemustaka, hanya saja di berikan sanksi. Jika pemustaka menghilangkan koleksi maka pemustaka harus menggantinya sesuai dengan judul buku yang dihilangkannya. 
Menurut Ibu Aji salah satu pustakawan di Perpusda terebut menyatakan:

Tidak ada biaya apapun yang di pungutkan kepada pemustaka, karena sudah aturan setiap perpustakaan, kita bisa mendapatkan ilmu dengan gratis pula.

Kesimpulan oleh penulis, dalam hal pemberian "Harga" terhadap jasa yang diberikan oleh pustakawan kepada pemustaka, tidak berupa uang (materi) tetapi harga yang di maksud disini adalah ganjaran atau hukuman atas kelalaian pemustaka terhadap aturan yang wajib di taati dan dikuti oleh seluruh anggota perpustakaan yang secara substantiv akan memberikan kerugian secara materil seperti adigium mengatakan Time Is Money yang artinya waktu adalah uang, jadi ganjaran yang diberikan kepada mahasiswa yang terlambat mengembalikan buku, dikenakan sangsi tidak diperbolehkan meminjam buku selama kurun waktu tertentu, tergantung berapa lama pemustaka tersebut telat mengembalikan buku, maka selama itu juga pemustaka tersebut tidak diperkenankan untuk meminjam buku. Rugi waktu maka rugi materi.

\section{c. Place}

Place ( tempat), adalah memilih lokasi untuk mengelolah saluran pemasaran yang di pakai untuk menyalurkan produk atau jasa.

Berdasarkan hasil wawancara yang dilakukan di Dinas Perpustakaan Dan Kerasipan provinsi nusa Tenggara barat, dalam hal, Apakah Lokasi/tempat perpustakaan strategis atau tidak dalam meningkatkan minat baca pemustaka di perpustakaan? seperti yang di ungkapkan oleh beberapa pustakawan sebagai berikut:

Menurut Ibu Hermin salah satu pustakawan di Perpusda terebut menyatakan:

Tempat perpustakaannya sangat strategis. Orangorang bisa datang dengan mudah. Dekat sama rumahnya juga ya itu yang membuat orang mau datang.

Menurut Ibu Wayan Dayu salah satu pustakawan di Perpusda terebut menyatakan:

Lokasi disini sangat strategis karena berdekatan dengan lembaga-lembaga pendidikan dan instansi lainnya, dan jumlah pengunjung pun tiap tahun meningkat, mungkin karena lokasinya yang dekat.

Menurut Ibu Aji salah satu pustakawan di Perpusda terebut menyatakan:

Perpustkaan disini lokasinya sangat stragtegis karena gampang di jangkau oleh pemustaka dan banyak pengunjung yang datang kesini karena berdekatan juga dengan sekolah dan instansi lainnya.

Adapun dapat disimpulkan oleh penulis, Dinas Perpustakaan dan Kearsipan Provinsi NTB lokasi nya sangat strategis karena terletak di tengah-tengah pusat Pendidikan, pusat pemerintahan, dan pusat aktivitas masyarakat. Di dalam rungan Dinas Perpustakaan dan Kearsipan Provinsi NTB juga dilengkapi fasilitas penunjang seperti CCTV, AC, Loker/tempat penitipan, parkir, ruang baca, ruang koleksi, ruang internet yang seluruhnya diperuntuhkan untuk memberi kenyamanan kepada seluruh pengunjung di Dinas Perpustakaan dan Kearsipan Provinsi NTB.

\section{d. Promotion}

Promotion ( promosi ), adalah suatu unsur yang digunakan untuk memberitahukan dan membujuk pasar tentang produk atau jasa yang baru pada perusahaan melalui iklan, penjualan pribadi, promosi penjualan, maupun publikasi.

Berdasarkan hasil wawancara yang dilakukan di Dinas Perpustakaan Dan Kerasipan provinsi nusa Tenggara barat, dalam hal, Bagaimana strategi promosi perpustakaan dalam meningkatkan minat baca masyarakat? seperti yang di ungkapkan oleh beberapa pustakawan sebagai berikut:

Menurut Ibu Aji salah satu pustakawan di Perpusda terebut menyatakan:

"Promosi disini dengan cara Mengadakan bimbingan teknis, yang diadakan di sekolah, rumah ibadah, pesantren. Kemudian ada juga yang melalui perpustakaan keliling, Perpustakaan keliling disini yang bergerak dengan membawa bahan pustaka seperti buku, majalah, koran dan bahan pustaka lainnya untuk melayani masyarakat dari satu tempat ke tempat yang lain.. Dengan adanya perpustakan keliling masyarakat di daerah dapat menikmati layanan informasi untuk meningkatkan pengetahuan mereka. Dinas Perpustakaan Dan Kearsipan Provinsi NTB melakukan roadshow ke beberapa post-post yang sudah di tetapkan yang ada Kota Mataram, dengan menggunakan perpustakaan keliling untuk membawa koleksi yang akan diperkenalkan oleh masyarakat. Dan kegiatan roadshow tersebut disesuaikan dengan jadwal kegiatan-kegiatan yang akan dilakukan setiap tahunnya" Selain itu perpustakaan keliling yang diadakan oleh Dinas Perpustakaan Dan Kearsipan Provinsi NTB bertujuan untuk meningkatkan gemar membaca dikalangan pelajar dan masyarakat umum serta sebagai objek sosialisasi koleksi buku baru yang dimiliki Dinas Perpustakaan Dan Kearsipan Provinsi NTB. Perpustakaan keliling ini beroperasi menuju sekolah-sekolah menawarkan koleksi yang dibawa untuk dibaca oleh pemustaka. Kemudian ada yang melalui sosialisasi dan ada juga mellaui lomba-lomba, seperti lomba bercerita, mendongen, menggambar, baca puisi ini dilakukan dalam rangka meningkatkan minat baca anak".

Adapun dapat disimpulkan oleh penulis, dalam melakukan promosi di Dinas Perpustakaan dan Kearsipan Provinsi NTB, banyak cara dilakukan mulai dari media Online sampai media cetak. Dua media ini yang menjadi alat untuk mempromosikan Dinas Perpustakaan dan Kearsipan Provinsi NTB.

Pertama media Online seperti internet dipilih karena memang disesuaikan dengan kebutuhan dan perkembangan serta gaya pemanfaatan informasi saat ini. Kedua memilih media cetak seperti brosur, dikarenakan masyarakat masih lebih suka membaca, melihat secara langsung, dan juga media ini jauh lebih murah dan efesien dan efektif sesuai dengan kultur budaya setempat. 


\section{E. KESIMPULAN DAN SARAN}

Berdasarkan penjelasan dan analisis sebagai hasil penelitian yang terkait dengan strategi promosi dalam penelitian ini menemukan bahwa strategi yang di gunakan Dinas Perpustakaan dan Arsip Daerah Provinsi NTB yaitu, menggunakan pendekatan product (produk), price (harga), place (tempat atau saluradistribusi), dan promotion (promosi).

1. Produk

Saat ini di Dinas Perpustakaan dan Kerasipan Provinsi Nusa Tenggara Barat memiliki koleksi yang cukup beragam dan sesuai dengan kebutuhan dari pemustaka. Selain itu perpustakaan juga melakukan Up Date Informasi dengan cara pembelian/pengadaan buku baru, secara sikologis koleksi baru ini akan menambah keinginan, kemauan, kepercayaan dan rasa nyaman dalam memanfaatkan informasi, sehingga di Dinas Perpustakaan dan Kerasipan Provinsi Nusa Tenggara Barat menjadikan cara tersebut sebagai salah satu upaya dalam promosi Dinas Perpustakaan dan Kerasipan Provinsi Nusa Tenggara Barat kepada masyarakat.

2. Price (Harga)

Dalam hal pemberian "Harga" terhadap jasa yang diberikan oleh pustakawan kepada pemustaka, tidak berupa uang (materi) tetapi harga yang di maksud disini adalah ganjaran atau hukuman atas kelalaian pemustaka terhadap aturan yang wajib di taati dan diikuti oleh seluruh anggota perpustakaan yang secara substantiv akan memberikan kerugian secara materil seperti adigium mengatakan Time Is Money yang artinya waktu adalah uang, jadi ganjaran yang diberikan kepada mahasiswa yang terlambat mengembalikan buku, dikenakan sangsi tidak diperbolehkan meminjam buku selama kurun waktu tertentu, tergantung berapa lama pemustaka tersebut telat mengembalikan buku, maka selama itu juga pemustaka tersebut tidak diperkenankan untuk meminjam buku. Rugi waktu maka rugi materi.

3. Place

Dinas Perpustakaan dan Kearsipan Provinsi NTB lokasi nya sangat strategis karena terletak di tengahtengah pusat Pendidikan, pusat pemerintahan, dan pusat aktivitas masyarakat. Di dalam rungan Dinas Perpustakaan dan Kearsipan Provinsi NTB juga dilengkapi fasilitas penunjang seperti CCTV, AC, Loker/tempat penitipan, parkir, ruang baca, ruang koleksi, ruang internet yang seluruhnya diperuntuhkan untuk memberi kenyamanan kepada seluruh pengunjung di Dinas Perpustakaan dan Kearsipan Provinsi NTB.

4. Promotion

Adapun dapat disimpulkan oleh penulis, dalam melakukan promosi di Dinas Perpustakaan dan Kearsipan Provinsi NTB, banyak cara dilakukan mulai dari media Online sampai media cetak. Dua media ini yang menjadi alat untuk mempromosikan Dinas Perpustakaan dan Kearsipan Provinsi NTB.

Pertama media Online seperti internet dipilih karena memang disesuaikan dengan kebutuhan dan perkembangan serta gaya pemanfaatan informasi saat ini. Kedua memilih media cetak seperti brosur, dikarenakan masyarakat masih lebih suka membaca, melihat secara langsung, dan juga media ini jauh lebih murah dan efesien dan efektif sesuai dengan kultur budaya setempat.

\section{DAFTAR RUJUKAN}

Bafadal, Ibrahim. 2008.Pengelolaan Perpustakaan Sekolah.Jakarta : Bumi Aksara

Kamus Besar BahasaIndonesia. Jakarta : Balai Pustaka

Singarimbun, Masri dan Sofyan Effendi, 1995. Metode Penelitian Surve. Cetakan ke 2, LP3ES, Jakarta.

Sugiyono. 2012. Untuk Metode Penelitian Kuantitatif Kualitatif dan $R \& D$. Bandung: Alfabeta.

Sulistyo_Basuki. 1991. Pengantar Ilmu Peprustakaan.Jakarta; PT Gramedia Pustaka Utama.

Sutarno NS, 2005. Perpustakaan dan Masyarakat, Jakarta: Yayasan Obor Indonesia.

Yusup, Pawit M. 2012, Perspektif Manajemen Pengetahuan,Informasi, Komunikasi, Pendidikan, dan Perpustakaan. Jakarta: Rajawali Pers.

Jurnal Kajian Informasi \& Perpustakaan, Agustina. 2013,Pengembangan Program Membaca di Perpustakaan salah satu komponen menjadi murid melek informasi, Vol. 1 No.1. Hal 131

Jurnal Pendidikan Penabur, Esther Kartika. 2004. Memacu Minat Baca Siswa Sekolah Dasar, No.03 / Th.III / Desember 2004.

Jurnal Magister Jurnal Unram, Lalu Suparman. 2017,Peran Pemimpin Dalam Melestarikan Dan Mengembangkan Budaya Organisasi Nahdlatul Wathan Pancor, Vol 6, No 4 (2017).

Ikhwan, 2017. Minat Baca NTB Rendah. Diakseshttps://kicknews.today/2017/03/08/minatbaca-masyarakat-ntb-rendah-duh-perpustakaandikalahkan-gaget/. Pada tanggal 28 Juni 2018.Jurnal Ulul Albab 